\title{
DETEKSI MOLEKULER EKSON 1 GEN BETA GLOBIN PADA PASIEN TALASEMIA BETA MAYOR DI RSUD DR. SOEROTO NGAWI DENGAN METODE POLYMERASE CHAIN REACTION (PCR)
}

\section{MOLECULAR DETECTION OF EXON 1 OF THE BETA GLOBIN GENE IN BETA THALASSEMIA MAJOR PATIENTS IN RSUD DR. SOEROTO NGAWI WITH POLYMERASE CHAIN REACTION (PCR) METHOD}

\author{
Agus Supriadi, ${ }^{,}$, Ana Indrayati2, ${ }^{2,}$, Elfahmi. $3,{ }^{*}$ \\ 1)2)Jurusan S2 Farmasi, Falkutas Farmasi, Universitas Setia Budi Surakarta-57127, Indonesia \\ *email: agoes.pharm@gmail.com \\ 3)Jurusan Farmasi, Falkutas Farmasi, Insitut Teknologi Bandung-40132, Indonesia
}

\begin{abstract}
ABSTRAK
Talasemia merupakan kelainan akibat mutasi gen yang bersifat autosumal resesif yang disebabkan kekurangan sintesis rantai globin pembentuk hemoglobin darah dengan gejala mirip anemia maka akan menurunkan produksi sel darah merah, dan harus dilakukan penanganan dengan dilakukan transfusi darah secara teratur.

Penelitian ini bertujuan mengetahui adanya mutasi pada ekson 1 gen beta globin pasien talasemia menggunakan metode PCR, dimana 5 sampel di isolasi DNA dan dilanjutkan amplifikasi PCR, hasil amplifikasi dielektroforesis region 1 gen beta globin Region I merupakan hasil amplifikasi dari primer forward 4 dan primer reverse 5 dengan target yaitu 322 bp, pada PCR terjadi amplifikasi atau penggandaan sekuen DNA yang diinginkan berdasarkan pemilihan primer untuk reaksi, produk PCR dari tiap region ini yang selanjutnya dilakukan SSCP.

Pada region I gen beta globin yang telah dilakukan analisis SSCP, satu sampel menunjukkan dua pita dengan pola yang berbeda dengan sampel $\mathrm{N}$ yaitu sampel 6 sedangkan pada empat sampel sisanya yaitu sampel 1,2,3,5 menampilkan tiga pita. Seluruh sampel menunjukkan pola yang berbeda dengan kontrol negatif (sampel N). Hal ini menunjukkan pada seluruh sampel ada indikasi mutasi.
\end{abstract}

Kata kunci : talasemia, beta talasemia, pcr

\section{ABSTRACT}

Talasemia is an autosumal recessive gene mutation caused by a lack of synthesis of hemoglobin-forming globin chains of blood with anemia-like symptoms will decrease the production of red blood cells, and should be treated with regular blood transfusions.

This study aims to determine the presence of mutations in exon 2 gene beta globin thalassemia patients using PCR method, where 5 samples in DNA isolation and continued PCR amplification, the amplification result of electrophoresis region 2 beta globin gene Region II is the result of amplification of primary 4 and primer primer reverse 5 with a target of $350 \mathrm{bp}$, on PCR there is amplification or doubling of the desired DNA sequence based on the primary selection for the reaction, the PCR product of each of these regions which is subsequently performed by SSCP.

In the SSCP result the five samples were found in one sample showing different ribbon pattern with the sample $\mathrm{N}$, there was sample 6 , while the remaining four samples, there were $1,2,3,5$ showed three bands. All the samples showed different from the $\mathrm{N}$ sample pattern. This shows that all samples indicated there were mutation.

Keywords: thalassemia, beta thalassemia, pcr 


\section{PENDAHULUAN}

Talasemia merupakan kelainan genetik akibat mutasi gen yang bersifat aotosumal resesif yang disebabkan kekurangan sintesis rantai globin pembentuk hemoglobin darah dengan gejala mirip anemia (Handayani dan Onggo, 2014).Talasemia merupakan kelompok kelainan yang diturunkan karena terjadi mutasi atau delesi pada gen yang menyandikan salah satu rantai globin sehingga terjadi penurunan kecepatan sintesis atau ketiadaan sintesis dari rantai globin. $\mathrm{Hal}$ ini menyebabkan penurunan kecepatan sintasis hemoglobin dan terjadi mikrositis (Bain, 2014).

Talasemia adalah penyakit kelainan darah yang disebabkan oleh sintesis globin yang tidak seimbang sehingga mengakibatkan kerusakan hemoglobin dan diturunkan secara resesif menurut hukum Mendel (Syamsudin, 2007). Talasemia disebabkan oleh penurunan kecepatan sintesis atau kemampuan produksi satu atau lebih rantai globin $\alpha, \beta$. Hal ini terjadi karena delesi total atau parsial gen globin, substitusi, atau insersi nukleotida. Beta talassemia adalah kelainan darah herediter yang ditandai dengan berkurangnya kadar $\mathrm{HbE}$ atau adanya sintesis $\beta$ globin, dengan adanya sintesis rantai globin yang tidak seimbang maka akan menurunkan produksi sel darah merah. Hal ini menyebabkan anemia dan harus di lakukan penanganan dengan dilakukan transfusi darah secara teratur agar keadaan kembali normal.

Penderita thalassemia yang melakukan transfusi darah secara rutin dapat meningkatkan zat besi dalam tubuh (Weatherall,1997). Salah satu cara yang sering digunakan untuk mengetahui pembawa sifat $\beta$ talassemia adalah dengan analisis hematologi, pembawa sifat $\beta$ talassemia dapat dilihat dengan gejala mikrositik dan penurunan jumlah $\mathrm{Hb}$ pada eritrosit (Cao \& Galanello, 2010). metode PCR-SSCP sebagai metode untuk mendeteksi mutasi pada pasien $\beta$ talasemia mayor. Metode ini telah dikembangkan untuk mendeteksi adanya mutasi pada pembawa sifat thalasemia (Priyambodo, 2014; Onggo, 2014).

Individu yang terdiagnosa individu $\beta$ talassemia mayor di RSUD Dr. Soeroto Kabupaten Ngawi dilakukan pemeriksaan $\mathrm{Hb}$ elektroforesis untuk penentuan diagnosanya dan belum adanya pemeriksaan molekuler untuk mengetahui jenis dan letak mutasi. Analisis PCR-SSCP terhadap individu $\beta$ talassemia menunjukan adanya mutasi pada gen $\beta$ globin (Priyambodo, 2014). Sehubungan dengan hal tersebut, maka dirumuskan permasalahannya yaitu apakah metode PCR-SSCP dapat mengetahui mutasi pada ekson 1 gen BETA globin, dengan ini sehingga tujuan penilitian dapat tercapai yaitu mengetahui adanya mutasi pada pasien talasemia ekson 1.

\section{METODE PENELITIAN}

\section{Alat dan Bahan}

1. Alat

Alat yang digunakan dalam penelitian ini meliputi serangkaian alat gelas berupa gelas beker, gelas ukur, Erlenmeyer, pipet tetes, corong, pengaduk, pipet ukur beserta pipet 
pump berfungsi untuk preparasi larutan baik bahan, sampel dan reagen, microcentrifuge tube (mictotube) $1,5 \mathrm{~mL}$ dan $0,2 \mathrm{~mL}$ sebagai tempat penyimpanan sampel, mikropipet untuk mengambil sampel dan bahan dalam skala microliter, neraca analitik untuk menimbang bahan, erlenmeyer untuk tempat pencampuran bahan, vorteks untuk homogenasi larutan, sentrifuge untuk memisahkan komponen larutan berdasar berat jenis, incubator sebagai tempat inkubasi, microwave untuk pembuatan gel agarose, lemari pendingin sebagai tempat penyimpanan bahan, rangkaian alat elektroforator horizontal untuk memisahkan komponen atau molekul berdasarkan perbedaan tingkat migrasinya dalam sebuah medan listrik, UV transiluminator untuk visualisasi pita DNA, thermocycler untuk amplifikasi DNA, fluorometer untuk mengukur konsentrasi sampel, dan kamera digital untuk dokumentasi selama penelitian.

2. Bahan

Bahan yang digunakan adalah 5 sampel darah pasien thalasemia yang rutin melakukan tranfusi di RSUD Dr. Soeroto Kabupaten Ngawi, disimpan dalam tube $B D$ vacutainer EDTA dan satu sampel normal atau control negative digunakan sebagai pembanding dalam penelitian ini. Bahan yang digunakan pada penelitian ini meliputi akuades steril, Geneaid Genomic DNA Mini Kit (Blood/Cultured Cell), PCR master mix KAPA $2 G$ fast ready mix, primer forward dan reverse spesifik untuk pada gen beta globin, DNA loading dye, Geneaid100bp plus DNA ladder, fluoroceft, gel agarosa, ethanol absolut $96 \%$, buffer Tris Borat
EDTA (TBE), loading buffer (campuran bromo phenol blue, formamide, EDTA, gliserol), gel poliakrilamid (acrylamide:bis-acrylamide 29:1). ethidium bromide dan pipet tip.

1. Pengambilan Sampel

Sampel darah diperoleh dari pasien beta thalasemia mayor yang rutin melakukan transfusi di RSUD Dr. Soeroto kabupaten Ngawi. Sampel darah disimpan dalam tabung vacutaine EDTA $3 \mathrm{ml}$ dan dimasukan dalam freezer- $20^{\circ} \mathrm{C}$.

\section{Isolasi DNA}

Isolasi DNA sampel dilakukan dengan GSYNC $^{\text {TM }}$ DNA Ekstraction kit sesuai dengan protocol kit. Langkah-langkah isolasi DNA sebagai berikut

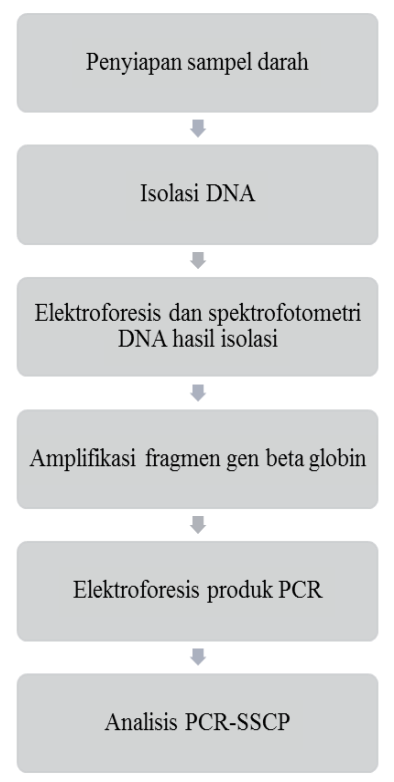

\section{a. Lisis Sel}

Sebanyak $200 \mu$ l sampel darah diambil dan dimasukkan dalam tabung microtube 1,5 ml dan menambahkan 20 $\mu$ Proteinase-K dan di inkubasi pada suhu $60^{\circ} \mathrm{C}$ selama 5 menit, kemudian ditambahkan GB buffer sebanyak 200 
$\mu$ dan dihomogenkan dengan vortex. Selanjutnya sampel diinkubasi pada suhu $60^{\circ} \mathrm{C}$ selama 5 menit, selama inkubasi microtube dibolak-balik selama 2 menit.

b. Pengikatan DNA

Setelah inkubasi selesai, sebanyak 200 $\mu$ l etanol absolut ditambahkan dalam sampel lalu divorteks kemudian dipindahkan dalam purification columm (kolom GD ) yang diletakakan dalam tabung pengumpul berukuran $2 \mathrm{ml}$. Sampel kemudian dipindahkan dalam kolom GD. Sampel selanjutnya di sentrifugasi pada 12.000 rcf selama 5 menit kemudian larutanan hasil sentrifugasi dibuang dan kolom $G D$ ditempatkan pada tabung pengumpul yang baru.

\section{c. Pencucian}

Sebanyak $400 \mu$ l wash buffer 1 ditambahkan ke dalam kolom GD dan disentrifugasi pada 12.000 rcf selama 2 menit. Larutan sisa pencucian pada tabung pengumpul dibuang. Kolom GD dimasukan ke dalam tabung pengumpul yang baru dan ditambahkan $600 \mu \mathrm{l}$ wash buffer II dan selanjutnya disentrifugasi pada $12.000 \mathrm{rpm}$ selama 2 menit. Larutan sisa pencucian dalam tabung pengumpul dibuang, kemudian kolom GD disentrifugasi lagi dengan kecepatas 12.000 rpm selama 4 menit.

\section{d. Pengelusian}

Setelah selesai, kolom GD ditempatkan dalam tabung microtube $1,5 \mathrm{ml}$, kemudian ditambahkan $75 \mu \mathrm{l}$ buffer elusi yang diinkubasi pada suhu $60^{\circ} \mathrm{C}$. Selanjutnya larutan diinkubasi pada suhu kamar selama 5 menit dan disentrifugasi pada 12.000 rcf selama 2 menit. Proses elusi diulangi 2 kali untuk memaksimalkan pelepasan DNA dari silica gel pada kolom GD. Selanjutnya, kolom GD dikeluarkan dari microtube 1,5 $\mathrm{mL}$ dan disimpan di dalam lemari pendingin.

3. Fluorometer dan Elektroforesis DNA Pada penelitian ini digunakan uji kuantitatif dengan metode fluorometri, Qubit fluorometer adalah perangkat kuantifikasi DNA yang didasarkan pada intensitas fluoresensi dari label fluorosen yang mengikat DNA beruntai ganda (sdDNA) (Nakayama et al. 2016), selanjutanya skema fluoromrter disiapkan microtube berisi sampel dan 2 microtube tambahan untuk standard atas dan bawah (nol). Selanjutnya dilakukan pembuatan larutan uji (Working Solution) dengan cara : Larutan dihomogenasikan dengan vortex selama 2-3 detik, dipastikan tidak ada gelembung terbentuk. Larutan standard dibuat dengan cara Sebanyak 1-20 $\mu \mathrm{L}$ sampel dicampurkan dengan 199-180 $\mu \mathrm{L}$ larutan uji untuk mendapatkan larutan dengan volume akhir $200 \mu \mathrm{L}$. Microtube berisi sampel divorteks selama 2-3 detik tanpa terbentuk gelembung kemudian diinkubasi pada suhur uang selama 2 menit. Setelah itu, dilakukan pembacaan dengan mesin Qubit yang telah dinyalakan. Larutan uji dibaca terlebih dahulu selanjutnya sampel. Microtube dimasukkan pada Qubit fluorometer kemudian ditekan "Read" dan ditekan "Save" untuk menyimpan data.

Selanjutnya, uji kualitatif dengan elektroforesis pada gel agarosa $0,8 \%$. Mula-mula sebanyak 0,32 gram agarosa ditimbang kemudian 
ditambahkan $40 \mathrm{~mL}$ Tris Borate-EDTA (TBE) $1 \mathrm{X}$ dan dilarutkan sampai homogen. Larutan tersebut dipanaskan dalam microwave selama 30 detik. Setelah sedikit dingin ditambahkan fluoroceft sebanyak $2 \mu \mathrm{L}$ dan dilarutkan hingga homogen. Gel dituang pada cetakan yang telah diberi sisir untuk sumuran. Gel didiamkan hingga mengembang lalu sisir dilepas dan gel dipindahkan ke dalam alat elektroforesis dan ditambahkan dengan TBE 1 $x$ hingga gel terendam.

Sumuran pertama diisi sebanyak $3,5 \mu \mathrm{L}$ marker DNA berupa 100 pb. Hasil isolasi DNA diambil sebanyak $5 \mu \mathrm{L}$ dan dicampur dengan $1 \mu \mathrm{L}(6 \mathrm{x})$ loading dye. Campuran DNA dan loading dye dimasukkan dalam sumuran gel agarosa. Elektroforesis DNA dilakukan dengan menghubungkan katoda dan anoda pada sumber tegangan 100 volt selama 15 menit. Pengamatan pita DNA dilakukan dengan menggunakan UV transiluminator.

4. Amplifikasi Region 2 Gen $\beta$-globin Hasil isolasi DNA akan digunakan sebagai cetakan pada proses amplifikasi dengan metode polymerase chain reaction (PCR). PCR dilakukan berdasarkan prosedur KAPA Biosystem (2013). PCR mix dibuat dengan menggunakan PCR Master mix KAPA2G fast ready mix,

Setelah semua komponen dimasukan ke dalam tabung PCR, selanjutnya dimasukan ke dalam mesin thermal cycler. Kondisi siklus PCR yang digunakan untuk amplifikasi gen $\beta$ globin adala sebagai berikut: (Pryambodo, 2014).

\section{Elektroforesis Hasil Amplifikasi PCR}

Hasil PCR dielektroforesis pada gel agarosa dengan konsentrasi $2 \%$. Sebanyak 0,8 gram agarosa ditimbang kemudian ditambahkan $100 \mathrm{~mL}$ Tris Borate-EDTA (TBE) 1X dan dilarutkan sampai homogen. Larutan tersebut dipanaskan dalam microwave selama 50 detik. Setelah sedikit dingin ditambahkan fluoroceft sebanyak 3,5 $\mu \mathrm{L}$ dan dilarutkan hingga homogen. Gel dituang pada cetakan yang telah diberi sisir untuk sumuran. Gel didiamkan hingga mengembanglalu sisir dilepas dan gel dipindahkan ke dalam alat elektroforesis dan ditambahkan dengan TBE 1x hingga gel terendam.

Sumuran pertama diisi dengan sebanyak $3 \mu \mathrm{L}$ marker DNA berupa 100 pb. Sampel diambil sebanyak $4 \mu \mathrm{L}$ dan dimasukkan dalam sumuran gel agarosa. Elektroforesis DNA dilakukan dengan menghubungkan katoda dan anoda pada sumber tegangan 50 volt. Elektroforesis dihentikan setelah migrasi DNA mencapai 2/3 panjang gel yang ditunjukkan dengan warna biru pada gel agarosa. Pengamatan pita DNA dilakukan dengan menggunakan UV Transiluminator.

\section{Analisis PCR-SSCP}

Analisis polymerase chain reactionsingle strand conformation polymorphism (PCR-SSCP) dilakukan berdasarkan metode dengan modifikasi sebagai berikut :

a. Pembuatan gel

Larutan gel disiapkandengan Erlenmeyer $125 \mathrm{ml}$ yang terdiriatas 5,6 $\mathrm{ml}$ aquabides $2,6 \mathrm{ml}$, poliakrilamid $30 \%$ (akrilamid : bisaakrilamid 29:1), $1 \mathrm{ml}$ 
TBE 10x, 0,68 ml gliserol 87\%, $45 \mu \mathrm{l}$ ammonium persulfat $10 \%$, dan $10 \mu \mathrm{l}$ tetramethyl ethylene diamine (TEMED). Setelah TEMED ditambahkan, larutan gel dihomogenkan, selanjutnya segera dituangkan dengan menggunakan mikropipet ke dalam cetakan. Sisir dipasang pada cetakan dan gel dibiarkan selama 60 menit.

Setelah 60 menit, gel dipasang pada tangki elektroforator vertikal dan ditambahkan TBE 1,5x hingga mencapai batas kolom. Sisir diangkat dengan hati-hati dan dilakukan prerunning selama 20 menit.

b. Penyiapan sampel

Sebanyak $10 \mu \mathrm{l}$ produk PCR ditambahkan $15 \mu \mathrm{l}$ loading buffer dihomogenasi dengan vortex. Campuran sampel dan loading buffer dipanaskan dalam waterbath pada suhu $95^{\circ} \mathrm{C}$ selama 10 menit untuk denaturasi. Setelah proses denaturasi, sampel segera dimasukkan freezer suhu $-20^{\circ} \mathrm{C}$ selama 10 menit. Setelah proses thawing, sebanyak $25 \mu \mathrm{l}$ campuran tersebut dimasukkan kedalam masingmasing sumuran gel. Elektroforesis dilakukan dengan TBE $0,5 x$ pada $100 \mathrm{~V}$ $50 \mathrm{~mA}$ selama 100 menit.

\section{c. Pewarnaan}

Gel dilepas dari gelas, lalu diencerkan dalam larutan etidium bromida selama 45 menit dan diamati dengan UV transilluminator. Hasil didokumentasikan dengan kamera digital.

d. Interpretasi hasil

Interpretasi data dilakukan dengan mendeskripsikan pita hasil SSCP dengan membandingkan perbedaan jarak migrasi pita (Single strand DNA) subyek yang diteliti dengan individu normal. Individu yang memiliki genotip homozigot, baik homozigot dominan maupun resesif menunjukkan dua pita DNA pada gel, sedangkan individu heterozigot menunjukan tiga atau empat pita DNA.

\section{HASIL PENELITIAN DAN PEMBAHASAN}

A. Identifikasi Sampel

Penelitian ini menggunakan sampel darah pasien yang terdiagnosa beta talasemia mayor dan melakukan transfusi darah secara rutin di RSUD Dr.Soeroto, Kabupaten Ngawi,Jawa Timur, dengan prosedur pengambilan sampel memenuhi kelayakan etik atau Ethical Clearance.

B. Pengambilan Sampel

Sampel darah diperoleh dari 5 (lima) pasien beta talasemia mayor yang rutin melakukan transfusi darah di RSUD Dr. Soeroto, Kabupaten Ngawi.

Sampel darah disimpan dalam tabung vacutaine EDTA $3 \mathrm{ml}$ dan dimasukan dalam freezer- $20^{\circ} \mathrm{C}$.

C. Hasil Isolasi DNA

Isolasi DNA ke sembilan sampel penelitian menggunakan $g S Y N C^{T M}$ DNA Ekstraction (Blood Protocol Prosedur). Isolasi DNA dilakukan dengan mengekstraksi DNA dari darah beku dan telah ditambahkan zat antikoagulan (EDTA). Hasil uji kualitatif dan kuantitatif DNA genom dapat dilihat di gambar 5 dan tabel 4. Uji kualitatif DNA dilakukan dengan elektroforesis pada gel agarosa dengan konsentrasi 0,8\%.Uji kuantitatif DNA dilakukan dengan metode fluorometri untuk 
mengetahui konsentrasi DNA hasil isolasi.

Pada elektroforesis DNA seluruh sampel didapat pita DNA yang terlihat jelas pada semua sampel menunjukkan keberadaan DNA dan keberhasilan isolasi DNA yang dilakukan. Selain 5 sampel diatas, satu sampel normal $(\mathrm{N})$ dan satu sampel kontrol positif $(\mathrm{K}+)$ juga dilakukan isolasi, namun tidak pada hasil elektroforesis yang sama.

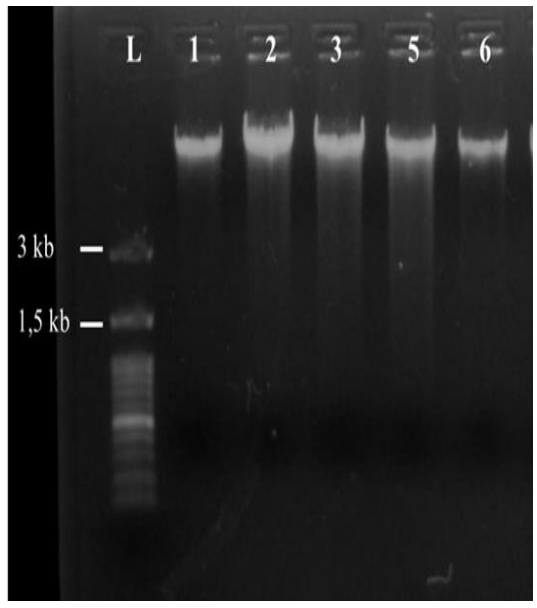

Gambar 1.Hasil elektroforesis isolasi DNA sampel penelitian

Sampel normal digunakan sebagai kontrol negatif mutasi. Sedangkan sampel $\mathrm{K}+$ yang digunakan merupakan sampel darah dari penyandang talasemia yang telah diketahui mutasinya melalui sekuensing DNA. Kedua kontrol ini digunakan untuk mengevaluasi setiap tahapan metode dari uji molekuler yang dilakukan.

Ukuran genom manusia berdasarkan International Human Genome Sequencing Consortium secara keseluruhan diestimasikan $2.916 \mathrm{gb}$, dengan ukuran molekul DNA pada 23 kromsosomnya berkisar dari
21,8 mb (kromosom $Y$ ) hingga 2692,9 mb (kromosom 1) dan molekul DNA pada mitokondria yang berukuran 16.569 pb (Lander, et al, 2001). Dikarenakan ukuran DNA nya yang besar sehingga pada hasil elektroforesis pita DNA genom sampel terlihat jauh diatas marker. Setiap sampel menampilkan pita dengan ketebalan yang beragam berdasarkan konsentrasi DNA yang diperoleh dari isolasi yang dilakukan. Pita yang tebal dan terang menunjukan bahwa DNA yang berhasil diisolasi memiliki konsentrasi yang lebih banyak, sedangkan pita tipis dan kurang terang menunjukan konsentrasi DNA yang lebih sedikit. Untuk memastikan konsentrasi dan kualitas DNA, kemudian dilakukan fluorometri.

Nilai konsentrasi DNA hasil isolasi sampel dengan metode fluorometri menggunakan Qubit Fluorometer ditampilkan pada Tabel 1. Pada sampel, konsentrasi DNA berkisar 55,2-82 ng/ $\mu \mathrm{L}$. Qubit Fluorometer adalah perangkat kuantifikasi DNA yang didasarkan pada intensitas fluoresensi dari label fluorosen yang mengikat DNA beruntai ganda (dsDNA) (Nakayama,et al. 2016). DNA pada sampel menunjukkan, konsentrasi yang bervariasi dengan sesuai dengan kenampakan tebal tipis pita pada elektroforesis. Setiap sel diploid manusia mengandung sekitar 6 pg

\begin{tabular}{lll}
\hline No & $\begin{array}{l}\text { Nama } \\
\text { Sampel }\end{array}$ & $\begin{array}{l}\text { Konsentrasi } \\
(\mathbf{n g} / \boldsymbol{\mu l})\end{array}$ \\
\hline 1 & Sampel 1 & 63,6 \\
2 & Sampel 2 & 68 \\
3 & Sampel 3 & 82 \\
4 & Sampel 5 & 70,8 \\
5 & Sampel 6 & 62 \\
\hline
\end{tabular}


DNA. Untuk isolasi DNA dari darah tepi umumnya diperoleh $30 \mathrm{ng} / \mu \mathrm{L}$ hingga 60 $\mathrm{ng} / \mu \mathrm{L}$ dari $1 \mathrm{ml}$ darah yang berasal dari 5-10 juta leukosit. Secara umum konsentrasi yang diperoleh relatif sesuai referensi diatas. Adanya variasi pada konsentrasi DNA dapat disebabkan karena kualitas darah yang berbeda salah satunya dikarenakan beda waktu saat penyimpanan darah.

\section{Hasil Amplifikasi Region I Gen Beta Globin}

Penelitian ini mengacu pada pembagian region berdasarkan Gupta dan Argawal (2003) dengan hanya difokuskan pada region (daerah) I yang dilakukan amplifikasi. Region I dipilih berdasarkan keberadaan daerah ekson I. Mutasi yang terjadi pada ekson dapat menyebabkan kesalahan translasi pada sintesis asam amino sehingga dapat memberikan efek secara langsung pada rantai beta globin yang disintesis. Proses amplifikasi atau perbanyakan DNA dilakukan dengan metode PCR.

Amplifikasi DNA dilakukan dengan menggunakan primer untuk melipatgandakan daerah ekson I pada gen HBB penyandi beta globin. DNA hasil isolasi kemudian dijadikan template dalam proses amplifikasi. Amplifikasi dilakukan pada daerah I gen beta globin (gambar 4), karena daerah tersebut merupakan tempat ekson I berada. Amplifikasi menghasilkan ukuran aplikon $322 \mathrm{pb}$, yang meliputi daerah 5' Untranslated Region (UTR), seluruh daerah ekson I dan sebagian daerah intron atau Intervening Sequence (IVS) 1 gen beta globin. Produk amplifikasi kemudian dianalisis dengan elektroforesis pada agarosa konsentrasi $2 \%$ untuk memastikan ada tidaknya amplikon target. Hasil elektroforesis produk amplifikasi DNA sampel penelitian dapat dilihat pada gambar 2.

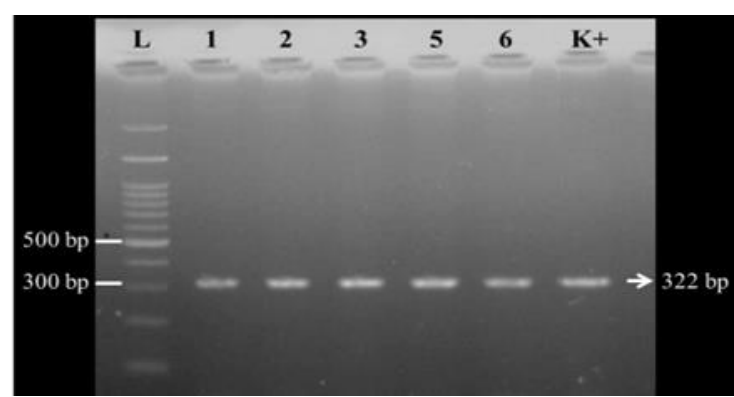

Gambar 2. Hasil elektroforesis region I gen beta globin pada sampel

Gambar 2 menunjukan DNA target dari semua sampel penelitian berhasil teramplifikasi. Hasil tersebut dapat dikonfirmasi dengan membandingkan ukuran DNA marker dengan ukuran amplikon dari sumber acuan (Gupta and Agrawal, 2003).

Pada PCR terjadi amplifikasi atau penggandaan sekuen DNA yang diinginkan berdasarkan pemilihan primer untuk reaksi. Penggandaan DNA secara alami terjadi pada organisme melalui proses replikasi DNA dengan DNA helikase berperan dalam membuka pita ganda DNA sehingga DNA polimerase dapat memulai penggandaan. Pada PCR peran DNA helikase digantikan dengan menaikkan suhu ketika reaksi sehingga DNA terdenaturasi dan terbentuk untai tunggal DNA, kemudian titik untuk memulai polimerasi ditentukan oleh primer yang spesifik yang melekat pada untai tunggal dan kemudian oleh DNA polimerase penggandaan sekuen DNA target terjadi. PCR memerlukan enzim polimerasi DNA yang tahan terhadap 
panas (thermostable) contohnya Taq Polymerase (Bustin, 2010). Produk PCR dari region 1 yang selanjutnya dilakukan SSCP.

\section{Hasil SSCP Region I Gen Beta Globin}

Single Strand Conformation Polymorphism atau yang dikenal sebagai SSCP merupakan salah satu teknik untuk mendetesi mutasi. Metode SSCP dilakukan untuk melihat pola migrasi untai tunggal DNA pada gel poliakrilamid. Setiap amplikon DNA pada region 1 dipisahkan dalam gel poliakrilamid selanjutnya diwarnai dengan ethidium bromide.

Prinsip dasar dari SSCP adalah fakta bahwa single strand DNA (ssDNA) memiliki konformasi tertentu. Perubahan konformasi karena adanya perubahan basa pada sekuen DNA dapat menyebabkan perbedaan migrasi ssDNA pada elektroforesis sehingga DNA wild-type atau normal dan DNA yang mengalami mutasi akan menunjukkan pola pita yang berbeda.

Analisis SSCP sendiri terdiri dari 4 tahapan yaitu : 1). Amplifikasi target DNA dalam hal ini yaitu region I gen beta globin, 2). Denaturasi dsDNA dari produk PCR menjadi ssDNA dengan penambahan agen denaturasi (formamida) dan pemanasan, 3). Pendinginan hasil denaturasi DNA yaitu ssDNA untuk memaksimalkan selfannealing sehingga membentuk konformasi tertentu, dan 4). Deteksi perbedaan migrasi konformasi ssDNA pada elektroforesis kondisi non denaturasi (Dong dan Zhu, 2005). Elektroforesis yang dilakukan adalah PAGE atau Polyacrilamide Gel
Electroforesis konsentrasi $39,7 \%$ dengan elektroforator vertikal.

Individu yang memiliki genotip homozigot hanya akan menunjukan dua pita DNA pada hasil elektroforesis gel poliakrilamid, baik homozigot dominan maupun resesif, sedangkan individu dengan genotip heterozigot mempunyai sepasang alel yang berbeda, satu alel normal dan satu alel mutan, sehingga hasil elektrofiresis gel poliakrilamid akan menunjukan lebih dari dua pita. Individu dengan genotip heterozigot dapat menunjukan tiga atau empat pita DNA pada gel poliakrilamid. Sampel penelitian yang menunjukan tiga pita pada hasil PCR-SSCP dikarenakan adanya asosiasi antara basa nukleotida penyusun untai tunggal DNA sehingga membentuk konformasi yang sama.Hasil dari analisis SSCP pada region I yang didalamnya juga termasuk bagian ekson I ditampilkan pada gambar 3 dan gambar 4 .

Indikasi adanya mutasi pada sekuen region I gen beta globin diketahui dengan melihat adanya pola pita yang berbeda dengan kontrol negatif (sampel $\mathrm{N}$ ).

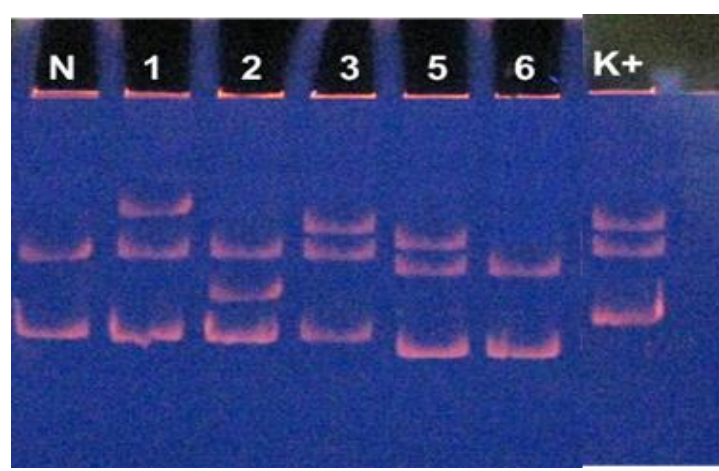

Gambar 3.Hasil analisis SSCP pada region I gen beta globin. Pola pita pada gel poliakrilamid. 


\section{$\begin{array}{lllllll}\mathrm{N} & 1 & 2 & 3 & 5 & 6 & \mathrm{~K}+\end{array}$}

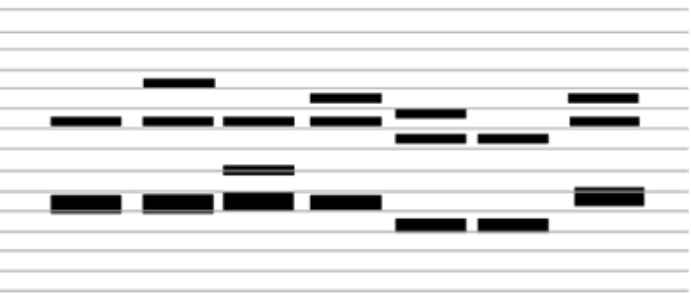

Gambar 4. Hasil analisis SSCP region Igen beta globin. Skema pola pita gel poliakrilamid.

Berdasarkan gambar 4 diketahui untuk region I seluruh sampel menunjukkan pola yang berbeda dengan sampel $\mathrm{N}$ sehingga seluruh sampel terdapat adanya indikasi terjadi mutasi

\section{KESIMPULAN}

Pada region I gen beta globin yang telah dilakukan analisis SSCP, satu sampel menunjukkan dua pita dengan pola yang berbeda dengan sampel $\mathrm{N}$ yaitu sampel 6 sedangkan pada empat sampel sisanya yaitu sampel 1,2,3,5 menampilkan tiga pita. Seluruh sampel menunjukkan pola yang berbeda dengan kontrol negatif (sampel N). Hal ini menunjukkan pada seluruh sampel ada indikasi mutasi.

\section{DAFTAR PUSTAKA}

Bain, B.,J.,2014, Hematologi, Kurikulum Inti, alih bahasa Anggraini Iriani, Buku Kedokteran, EGC.

Bustin, S. A., 2010.The PCR Revolution: Basic Technologies and Applications. Cambridge University Press. New York. hal 17.

Cao, A. \& Galanello, R. 2010. Bthalassemia. GeneTest Review.
Genetics in Medicine. 12 (2), 61 76.

Gupta, A. and Agrawal, S., 2003, Efficiency and Cost Effectivennes : Page-SSCP versus MDE and Phast Gels for the Indentification of Unknown $\beta$ Talasemia Mutation, Jurnal Molecular Pathology, 56, 237239.

Handayani,N.S. dan Onggo, A.T., 2014, Identifikasi Mutasi Gen $\beta$ Globin Ekson 1 pada Pembawa Talasemia, Jurnal Biogenesis, Vol. 2,I, hal. 63-69.

Nakayama Y. Yamaguchi H. Einaga N. and Esumi M. 2016.Pitfalls of DNA Quantification Using DNABinding Fluorescent Dyes and Suggested Solutions. Plos One;11(3): e0150528. doi: 10.1371/journal.pone.01505 $\underline{28}$

Priyambodo dan Handayani, N.S.N., 2014, Deteksi mutasi Ekson 2 Gen $\beta$-Globin dan Daerah Pengapitnya Pada Pembawa Sifat $\beta$-Talasemia dengan Metode Polymerase Chain Reaction-Singgle Strand Conformation

Polymorphism(PCR-SSCP), Prosiding Seminar Nasional dan Rapat Tahunan Bidang MIPA, Fakultas MIPA Institut Pertanian Bogor.

Weatherall, $\quad$ D.,J.,1997, The Thallasemias, Fortnightly Review, British Medical Journal, 314, 1675-1678. 